\title{
SEISMIC EFFECTS ON NUCLEAR INSTALLATIONS INTRODUCTION, SUMMARY AND RECOMMENDATIONS
}

Editor's Note

The following papers are excerpts from the submission of the Working Group for Seismic Effects on Nuclear Instablations to the 1977 Royal Commission on Nuclear Power.

The Working Group comprises members of the New Zealand Ministry of Works and Development, The Department of Scientific and Industrial Research and the Electricity Department and was established in 1971 under the auspices of the New Zealand Atomic Energy Committee with the following terms of reference:

- To exomine and report on problems relating to design requirements and the construction of nuclear reactor installations in New Zealand, resistant to seismic effects.

- To recommend such design requirementsand safety reguiations for inclusion

in New Zealand nuclear reactor installation specifications.

The 1977 report is the second publication by the Working Group. "Seismic Analysis of Nuclear Power Plants - Survey of Current State of the Art" was published in 1973. At the present time the Working Group comprises Mr. Hatrick (convenor) and Dr. Aspden of the M.W.D.; Messrs. Hitchcock, Thain and Wylde of the N.Z.E.D., : and Mr. Oborn (Geological Survey), Dr. Smith (Geophysics) and Dr. Skinner (Physics and Engineering Laboratory) of the D.S.I.R.

The contents of the 1977 report (titled "Report of the Working Group for Seismic Effects on Nuclear Installations", New Zealand Atomic Energy Committee, AEC 523, June 1977) are as follows :

\author{
Foreward \\ Table of Contents \\ Introduction and Summary \\ Recommendations \\ Chapter 1: Outline Description of Nuclear Power Reactors \\ Chapter 2: Potential Hazards from Earthquakes \\ Chopter 3: The Seismic Risk in New Zealand \\ Chapter 4: Criteria for Design and Assessment \\ Chapter 5: Geological Assurance \\ Chapter 6: Engineering \\ Chapter 7: Surveillance and Instrumentation
}

Those sections of the report which are of particular relevance to New Zealand are reproduced in the following pages. This includes the Introduction and Summary, Recommendations, Chapters 2, 3,5 and part of Chapter 4. The permission of the N.Z.A.E.C. to reproduce parts of the report is gratefully acknowledged.

\section{INTRODUCTION AND SUMMARY}

At the present time two trends are becoming apparent in the design and construction of nuclear reactors to resist earthquakes. An increasing number of countries are attempting to formulate their requirements as codes or guidelines; and the resources of research and development which are being devoted to the subject seem to increase year by year.

The first trend indicates a growing consensus among experts in most countries that the principles now being followed are unlikeiy to change greatly in the foreseeable future. The second trend indicates very clearly that within the accepted framework of these principles many important matters need further study.

This report begins with a brief survey of the nature of nuclear reactors, and the hazards to which they may be subjected, and which may arise from them, in earthquakes. The report is written almost entirely in terms of large power stations. However, the principles involved apply equally to small reactors and other nuclear installations.

Next follows a discussion of seismic risk in New Zealand. Most nuclear reactors in the world are built in areas where the seismic risk is considerably lower than in most of New zealand. Of those regions where seismic risk is of great importance, the seismicity of California is about the same as in New Zealand, while that of Japan is significantly higher. Some experience of earthquake damage in New Zealand is reported together with the limited experience of nuclear reactors in earthquakes. None has yet suffered damage from such a cause.

The possibility of large earthquakes occurring anywhere in the country cannot be precluded. Certain areas of the country do however appear to have lower seismic risk 
than others. Some recently published figures for seismic risk are presented in Chapter 3 of this report.

The criteria used for reactor design and assessment in other countries are reviewed, and it is evident that there is a strong trend towards adopting criteria which resemble, at least in principle, those used in the United States. For purposes of design and assessment of the safety of a particular reactor, two design earthquakes are specified, called the Safe shutdown Earthquake (SSE) and the Operating Basis Earthquake (OBE). In each case they are determined after assessing the seismic history and characteristics of the region, and the characteristics of the local geology.

The SSE is defined in terms such as "the maximum earthquake potential" (USA), or "the most unfavourable which is considered conceivable to occur" (Japan). A reactor experiencing a SSE must be able to be shutdown and maintained in a safe state. (Primarily this means able to transfer decay heat from the core and avoid fuel melt.) Beyond this requirement damage may be sustained which renders the reactor unusable.

The probability of a reactor experiencing an earthquake as severe as the SSE is extremely low, but a reactor in a seismic area is sure to experience some earthquakes. After one has happened, a decision has to be made as to whether it should be shut down, and inspected for damage. Obviously many earthquakes will be so small that such a move would be superfluous and costly. To define the level at which such a shutdown has to be made, the concept of the OBE has been introduced. This is the most severe earthquake which (it is agreed in advance) the reactor can sustain without any important part being at risk of damage. It is intended that after experiencing an earthquake as severe as the OBE the reactor should be capable of continued operation, without danger to the public; after any more severe earthquake it should be shut down, and not restarted until it has been inspected and declared safe.*

Measures to ensure that a reactor will in fact meet the design criteria are described. Geological assurance is required that the site will not be damaged by ground failure, land-slide or rock-fall; that the risk of tsunami or volcanic activity is acceptably low; that secondary damage from geological hazards elsewhere is small (e.g. a landslide blocking essential water supplies); and that as far as can be ascertained, the risk of ground disruption by faulting or fissuring is acceptably low.

Engineering assurance is needed that all parts of the reactor and associated plant are designed and constructed to the highest standards, and continue to meet these standards throughout the life of the plant. Such assurance is required of all reactors, whether they are built in seismic areas or not. But the need to

* At present there is considerable debate in the nuclear industry as to how an earthquake which exceeds the OBE criteria can be quickly identified. consider the earthquake risk introduces a new dimension. Consideration has to be given to lateral vibrations and resultant loadings; to fatigue effects due to alternating loadings; to the function of instruments under vibration conditions; and to the possibility of simultaneous damage to two or more systems which would, in the absence of an earthquake, be regarded as being independent of each other.

The report is the result of extensive study of overseas literature, and of limited discussions with experts from overseas, and with specialists in some fields in New Zealand. The Group has then applied its knowledge and experience of New Zealand conditions to formulate its recommendations. It cannot be stressed too strongly that these recommendations are no more than an expression of the Group's opinions as they are at the present time. It is possible that they will be modified as a result of future research and development. Nevertheless the group believes the standards of design and construction now employed provide an acceptable degree of confidence.

\section{RECOMMENDATIONS}

These recommendations are regarded by the Working Group as an expression of its opinion at the present time.

This opinion could be modified in some degree by the extensive research and development which is going on in New Zealand and overseas on seismic matters generally, and (overseas) on their application to reactor safety.

1. It has to be recognised that New Zealand would always be a small customer in the field of power reactors. It will not be in a strong position to specify its seismic requirements in a way unusual to the manufacturers, without incurring substantial cost penalties. To a great extent it will be necessary for New Zealand to ascertain what reactor manufacturers are prepared to offer, and then decide whether it is acceptable.

IT IS RECOMMENDED THEREFORE THAT NEW ZEALAND CRITERIA BE ESTABLISHED IN TERMS WHICH ARE FAMILIAR TO REACTOR SUPPLIERS.

2. Codes for design, and standards for materials, manufacture, inspection, testing and surveillance, already cover the general field of engineering. Many have special application to nuclear installations, and this class is being developed rapidly. The development is, at the present time, furthest advanced in the U.S.A. By the time New zealand has to make decisions on such matters there will be a substantial body of codes and standards defining U.S. safety requirements. These will be familiar to manufacturers in all countries from which New Zealand is likely to purchase a reactor.

IT IS RECOMMENDED THEREFORE THAT THE U.S. CODES AND STANDARDS BE USED AS A GUIDE BY WHICH NEW ZEALAND CAN JUDGE THE SAFETY OF WHAT IS OFFERED.

It is possible that in the course of time the International Standards Organisation will produce codes and standards for nuclear 
installations. The above recommendation may need to be changed in the light of such a development.

3. Each proposed reactor site should be assessed and shown to be adequately safe in terms of absence of unacceptable geological hazards. Such assessment should follow the guidelines in Appendix $A$ to "Reactor Site Criteria" issued by the U.S. Nuclear Regulatory Commission (usually cited as 10 CFR 100). However, the criteria therein relating to the assessment of risk from surface faulting are considered inappropriate for New Zealand conditions, and -

IT IS RECOMMENDED THAT THE RISK OF SURFACE FAULTING BE ASSESSED BY THE NEW ZEALAND LICENSING AUTHORITY AFTER CONSULTATION WITH GEOLOGISTS, GEOPHYSICISTS AND OTHER EARTH SCIENTISTS FAMILIAR WITH NEW ZEALAND CONDITIONS.

4. IT IS RECOMMENDED THAT FOR THE PURPOSE OF DEFINING, FOR REACTOR SUPPLIERS, WHAT NEW ZEALAND'S REQUIREMENTS ARE, THERE SHALL BE SPECIFIED FOR ANY SITE, A SAFE SHUT-DOWN EARTHQUAKE, AND AN OPERATING BASIS EARTHQUAKE. $100:$

They are defined as follows in $10 \mathrm{CFR}$

The "Safe Shut-down Earthquake" is that earthquake which is based upon an evaluation of the maximum earthquake potential considering the regional and local geology and seismology and specific characteristics of local subsurface material. It is that earthquake which produces the maximum vibratory ground motion for which certain structures, systems and components are designed to remain functional. These structures, systems and components are those necessary to assure:

(1) the integrity of the reactor coolant pressure boundary

(2) The capability to shut down the reactor and maintain it in a safe shut-down condition, or

(3) The capability to prevent or mitigate the consequences of accidents which could result in potential offsite exposures comparable to the guideline exposures of this part.

The "Operating Basis Earthquake" is that earthquake which, considering the regional and local geology and seismology and specific characteristics of local subsurface material, could reasonably be expected to affect the plant site during the operating life of the plant; it is that earthquake which produces the maximum vibratory ground motion for which those features of the nuclear power plant necessary for continued operation without undue risk to the health and safety of the public are designed to remain functional.

5. IT IS RECOMMENDED THAT THE SAFE SHUTDOWN EARTHQUAKE (SSE) BE SUFFICIENTLY SEVERE AND INFREQUENT THAT THE PROBAEILITY THAT IT WILL OCCUR DURING THE LIFE OF THE REACTOR, AND THAT THIS WILL CAUSE A RELEASE OF RADIOACTIVITY, CAN BE CONSIDERED NOT TO ADD SIGNIFICANTLY TO THE RISK OF SUCH A

\section{RELEASE FROM NON-SEISMIC CAUSES.}

The SSE should be established from consideration of all the information relevant to the site, including uncertainties due to lack of information.

The Operating Basis Earthquake (OBE) is to be, as a minimum, of a severity which might be expected to cccur at the site about once in 100 years. The reactor operator may choose to specify an OBE which is more severe.

NOTE: The Working Group considers that it is not possible in New Zealand, to specify the "maximum conceivable earthquake" (or any similar concept) in terms which can be conveyed to the supplier of a nuclear reactor, or to manufacturers of components. It is possible, however, to specify the SSE and OBE, as defined above, in such terms. Implicit in these definitions is the assessment, by a New Zealand Licensing Authority, of a degree of risk. The Working Group has in mind the method of assessment of seismically-induced hazard used in the USNRC "Reactor Safety Study" (WASH-1400). It does not advocate such an approach as being the last words on the matter, but it expects that further refinements will be made, which will prove a valuable tool in the hands of those who have to specify design earthquakes.

6. IT IS RECOMMENDED THAT A NEW ZEALAND LICENSING AUTHORITY SHOULD HAVE SOME STAFF WITH A SOUND KNOWLEDGE OF EARTHQUAKE ENGINEERING. THIS IS CONSIDERED ESSENTIAL FOR THE ADMINISTRATION OF THE ENGAGEMENT AND EMPLOYMENT OF OUTSIDE AGENCIES SUCH AS CONSULTANTS OR GOVERNMENT DEPARTMENTS.

7. IT IS RECOMMENDED THAT AT PROSPECTIVE NUCLEAR SITES INSTRUMENTS SHOULD BE INSTALLED TO RECORD TECTONIC INFORMATION. THIS SHOULD BE DONE AS EARLY AS POSSIBLE, BECAUSE LARGE EARTHQUAKES ARE RELATIVELY UNCOMMON, AND THE INFORMATION GAINED FROM RECORDING EVEN ONE, AT A SITE, WOULD BE VALUARLE.

8. IT IS RFCOMMENDED THAT THE WORKING GROUP SHOULD REMAIN IN BEING AND MAINTAIN A CONTINUING WATCH ON DEVELOPMENTS. 


\section{POTENTIAL HAZARDS FROM EARTHQUAKES*}

\subsection{Nature of the Earthquake Risk}

Risks always exist with a nuclear power station wherever it is sited due to the possibility of an accident which releases radioactive material to the environment. People in the region surrounding the reactor could be exposed to ionizing radiation both externally and through the ingestion and/or inhalation of the radioactive material. In extreme cases death could result, but the principal effect on human health would be to increase the risk of long term cancer in those exposed and of genetic effects in their offspring. Apart from humanhealth effects, a radioactivity release could also result in a loss of agricultural production. These effects have been discussed by the United States Nuclear Regulatory Commission (1975)(1) and by Sutton(2). Siting of a nuclear power plant in a seismic area does not change the nature of these risks but adds another event to the possible causes of an accident which releases radioactivity.

\subsection{Economic Aspects}

Conventional thermal power stations are designed for earthquakes so as to keep the economic risk from earthquakes low. Nuclear plant design levels are governed by considerations of public safety and will be higher than those for conventional thermal power plant. The economic risk associated with nuclear plants will consequently be smaller.

\subsection{Cooling Water Considerations}

A large power reactor would be designed to be safely shut down in the event of a major earthquake, but even in the shutdown state it is essential to provide some cooling; thus a cooling water supply adequate for this purpose must be available which can also withstand major earthquakes.

\subsection{Emergency Plans}

It is usually considered prudent despite the remote possibility of an accident at nuclear power plants to prepare emergency plans which would include measures such as the distribution of potassium iodate tablets and evacuation. A large earthquake could result in the disruption of communications, power supplies and transport systems and inhibit the implementation of such emergency measures. The siting and emergency planning for a nuclear plant in a seismic zone should take this into account.

* Chapter 2 of the 19.77 Report of the New Zealand Atomic Energy Committee Working Group on Seismic Effects on Nuclear Installations.

\subsection{Radioactive Waste Repository}

Apart from possibly causing damage at a nuclear power plant, seismic activity could potentially disturb the integrity of a high level waste repository, should such a repository be built in New Zealand. Such a repository could be for either spent fuel or reprocessed waste.

To the extent that a waste repository does not contain the same quantities of stored energy potentially available to disperse the radioactivity, the effect of an earthquake on waste repository would not be as immediately serious as on a power reactor. It is apparent however that similar care in the choice of site and in the design and construction of the facility should be used for a waste repository as would be applied in the building of a power reactor.

\section{REFERENCES}

1. United States Nuclear Regulatory Commission (1975), "Reactor Safety Study: An Assessment of Accident Risk in U.S. Commercial Nuclear Power Plants", WASH-1400.

2. Sutton, H. C., (1976), "Nuclear Energy in a Food Exporting Country", Evidence presented by DSIR to the Royal Commission on Nuclear Power Generation, December 1976 . 


\section{SEISMIC RISK IN NEW ZEALAND*}

\subsection{Nature of Earthquakes}

\subsubsection{Cause}

The uppermost $100 \mathrm{~km}$ of the Earth is undergoing continual deformation. The large amount of energy involved in deforming the rock is stored as strain energy, rather like that in a spring which has been compressed. Periodically the strain is relieved by rupture of the rock, or slippage along some previously formed fracture, and this constitutes an earthquake. Much of the strain energy is released as seismic energy, which radiates out through the Earth from the centre of the disturbance. This vibration is sometimes felt over distances of many hundreds of kilometres. It can be detected many thousands of kilometres away by sensitive instruments. Energy is also released in other forms, perhaps the most important of which is gravitational energy. At Napier in 1931 a large area was uplifted a metre or more.

\subsubsection{Vibration Effects}

Small earthquakes are felt over only very limited areas. Vibration from these tends to be of shorter duration and higher frequency content than from larger earthquakes. Large earthquakes have much more widespread effects. Accelerations comparable with that of gravity can be experienced, both in the vertical and horizontal directions. Strong ground motion generally lasts for less than one minute, although less severe shaking can persist for up to several minutes. (See 4.5.7 and Ref. (27) of Chapter 4.) Ground motion can be amplified on unconsolidated ground, or by focussing effects attributable to local geologic conditions.

\subsubsection{Geologic Effects}

In the immediate vicinity of the source region of large earthquakes, geologic effects can be significant. The surface along which the rupture takes place is usually at some depth below the earth's surface (perhaps 10-30 km) but can for large earthquakes extend to the surface. This is not as common in New Zealand as in certain other countries, but occurs frequently enough to be of importance. The differential motion can be vertical, as at Murchison in 1929 when an uplift of over four metres occurred, or horizontal, as at Inangahua in 1968 when a fence was displaced one metre and railway lines were severely affected by the lateral motion.

Large areas of land may be uplifted, as

* Chapter 3 of the 1977 Report of the New Zealand Atomic Energy Committee Working Group on Seismic Effects on Nuclear Installations. was mentioned in 3.1.1. Landslides may occur. Slumping is common. Geological effects are treated more fully in section 5.

\subsection{Definition of terms}

1. Magnitude - An instrumental measure of the size of an earthquake. This is not to be confused with the amount of vibration at any particular place (see Intensity). Defined by C. F. Richter in 1935, the scale is logarithmic. An increase of one unit in magnitude multiplies the energy release in the earthquake by about 30. The largest earthquake ever known to occur had a magnitude of about. 8.9.

2. Intensity - A measure of the amount of vibration at any particular place. The Modified Mercalli scale (see Appendix 3.1) takes values from I (not felt) to XII (total devastation). Intensity depends not only on the maximum ground acceleration and velocity but also on the predominant frequency and the duration.

3. Focus, or hypocentre - The point, often deep in the Earth, at which the earthquake rupture commenced.

4. Epicentre - The point on the Earth's surface directly above the focus.

5. Return period - The average time between occurrences, e.g., "a return period for magnitude earthquakes and greater of 100 years", which implies that such earthquakes are expected to occur about once a century. The probability that an event will occur once or more within its return period is about 64 per cent.

\subsection{Gccurrence of Earthquakes in New Zealand \\ 3.3.1 Historical}

Earthquake occurrence has been recognised in New Zealand from earliest times. Eiby (1968) (5) has published a list of the most important shocks. Earliest among these is a shock identified by Maori tradition as having occurred in the Wellington region about 1460. Early settlers in wanganui were dismayed at the damage from the earthquakes there in 1843. It became evident that the likelihood of the repetition of such an event should be taken into account in the construction of new buildings (Eiby, 1975)(6). The Marlborough earthquakes of 1848, which severely damaged Wellington, served to emphasise this.

The largest shock in historical times was the 1855 South-West Wairarapa earthquake (magnitude 8) which did extensive damage in wellington and was felt over much of the country. That earthquakes constitute a serious danger to the occupants of buildings 
as weIl as to the buildings themselves was emphasized at Napier in 1931 when 265 people died. It was after this that significant moves were made towards improving public safety in the event of an earthquake. Figure 3.1 shows the epicentres of all shocks above magnitude 7 since 1840 and all above magnitude 6 since 1940 .

\subsubsection{Seismo-Tectonic Setting}

New Zealand lies astride the almost continuous belt of seismic and volcanic activity that encircles the Pacific. Current theory describes the worldwide pattern of earthquake occurrence in terms of a number of rigid "plates" which constitute the uppermost $100 \mathrm{~km}$ or so of the Earth. The interaction between these plates results in earthquake activity in the vicinity of their boundaries, while their interiors are relatively stable.

The Hikurangi Trench, off the East Coast of the North Island, identifies such a plate margin. Here the Pacific Plate plunges in a north-westerly direction under the North Island, creating a dipping zone of deep earthquakes. Shallow activity extends over most of the North Island and the northern end of the South Island. In Fiordland the configuration is reversed, with the Indian Plate dipping south-eastwards under the South Island to create a zone of deep activity and, above it, more widespread shallow activity. Linking the two active regions is the Alpine Fault. The geological structure in the north-west Nelson matches that in Fiordland, implying that there have been large movements on the Fault in the past, although there seems to be little activity at present.

\subsubsection{Geographic Distribution}

No part of New Zealand is without earthquakes. There are concentrations of shocks in the Main Seismic Region, comprising the eastern and central North Island and the northern part of the South Island, and in the Fiordland region. In Northland and southeastern Otago there is a distinct paucity of activity, but these areas are by no means aseismic. Earthquakes near Kaitaia in 1963 (Eiby, 1964)(4) and Dunedin in 1974 (Adams and Kean, 1974) (1) were severe enough to do significant damage.

All parts of New Zealand are likely to experience shaking from large earthquakes, although the severity is likely to be less in Northland and south-eastern Otago. Localised high intensities will occur more frequently in the more seismically active parts of the country.

\subsubsection{Statistical Evaluation}

In attempting to quantify earthquake risk, the usual approach is to analyse statistically the past earthquake record. In New Zealand, earthquakes of magnitude 7 or more are thought to have been fully documented since about 1840 , but it is only since about 1940 that we have what is believed to be a complete record of smaller earthquakes. Present Seismological observatory practice is to document all earthquakes of magnitude greater than 4 , together with smaller shocks known to have been felt.
When seeking information about severe earthquakes that are expected to occur only once every few centuries or millenia, it is dangerous to assign high reliability to extrapolation from such a short time span, particularly as there is an increasing amount of evidence from around the world that seismic activity is subject to longterm variations.

The activity since 1840 , however, seems to imply that New Zealand can expect a great earthquake of the size of the 1855 event about once a century. A shock of magnitude 7 or greater can be expected about once a decade, one of magnitude 6 or more once a year, and one of magnitude 5 about ten times a year. It is difficult to estimate the frequency of shocks occurring in less seismic areas such as Northland and Otago, but the fact that earthquakes have occurred in both areas during the last 15 years indicates that they may well occur there again.

Dick (1965) (2) has used extreme-value theory to estimate the maximum magnitudes likely in different parts of the country. As he points out, however, evaluation of earthquake risk properly considers the intensities likely to be experienced rather than the magnitude. Large earthquakes do damage over wide areas. Figure 3.2 shows the intensities observed during the Hawke's Bay earthquake of 1931 and the Inangahua earthquake of 1968. Recent work (Smith, 1976) (8) has developed an expression for the intensity likely to be experienced at any given site from an earthquake of specified magnitude elsewhere. It is possible, therefore, to examine the earthquakes known to have occurred in New Zealand and estimate the likely return periods for damaging intensities at sites of interest. Such figures for the whole country are presented in Figure 3.3. The contoured value is the likely return period for intensity VIII, based on the earthquake record since 1840. South of Christchurch the figures are based on earthquake occurrence since 1940. The data for Northland are so sparse than an extrapolation to intensity VIII cannot be made with any confidence. It suffices to say that the risk there is much less than in other parts of the country, probably comparable to that in south-eastern Otago.

It should be stressed that such estimates are based on the assumption that earthquake activity since 1840 is characteristic of future activity. For short return periods this assumption is probably quite valid, but for return periods of 200 years and more it results in much less reliable estimates of risk.

A further important point is that the intensity formula developed by Smith (1976) and the return periods of Figure 3.3 refer to average soil conditions. When observed and calculated intensities are compared there is a standard deviation of about one intensity unit in most areas, due largely to the variation of soils and subsuriace structure within the region under study. That is, the intensity observed in an earthquake can vary by one unit or more within a very short distance. This corresponds to a factor of about three in the return 
period for any particular site.

\subsection{Relation of New Zealand Seismicity to the World Scene}

By world standards, New Zealand is a country of moderate earthquake risk. 75\% of the world's earthquakes occur around the border of the Pacific basin. A second major belt extends from South-East Asia westward to the Mediterranean. Earthquakes of generally smaller magnitudes occur on the mid-oceanic ridge system. We experience in New Zealand about 1\% of the world's large earthquakes, giving a level of seismicity comparable with that in California but many times less than that in, say, Japan, the Phillipines, or Chile.

\subsection{Earthquake Damage in New Zealand}

Most damage in New Zealand has been to structures not designed to resist lateral deformation. Wellington first began to lose chimneys in 1848. The 1855 earthquake left Wellington without a sound brick building. The upper portion of the Christchurch cathedral spire has been damaged several times. At Napier in 1931 the business blocks were nearly all masonry; many collapsed completely, and most were seriously damaged. A few better constructed buildings survived without damage.

Deformation of the ground surface is common especially on unconsolidated ground. This was particularly noticeable on the North Shore Causeway, Napier, in 1931, when the poorly constructed road slumped. The previously swampy land surrounding it is now dry, following a metre or more of regional uplift. At Inangahua in 1968 a landslide destroyed a house, killing the occupants. A spectacular example of fault movement was that at Murchison in 1929, when a fault scarp over four metres high was formed.

Almost all great earthquakes have been followed by fire. Cooking and heating facilities are overturned, and water mains cut. Fires have often been caused by attempts to use damaged equipment. Fire soon gained a hold on the business centre of Napier in 1931. Rubble in the streets hampered fire-fighting equipment.

Economically, earthquakes present a significant risk in New Zealand. After the Hawke's Bay earthquake of 1931, insurance companies paid out $\$ 250,000$ for losses they estimated at ten times that figure. Claims to the Earthquake and War Damage Commission after the Inangahua earthquake of 1968 exceeded $\$ 2,500,000$. During the five years to 1975, the Commission has paid out an average of over $\$ 200,000$ annually.

\section{REFERENCES}

1. Adams, R. D, and Kean, R. J., (1974), "The Dunedin Earthquake 9 April 1974, Part I: Seismological studies", Bull. N.Z. Nat. Soc. Earthquake Eng., 7 115-122 1974 .

2. Dick, I. D., 1965, "Extreme Value Theory and Earthquakes", 3rd World Conference on Earthquake Engineering, IVI, 45-52.

3. Eiby, G. A., 1957, "Earthouakes" Frederick Muller, 207 pp.
4. Eiby, G. A., 1964, "Northland Earthquakes of 1963 Nov-Dec. and the Seismicity of Northland", N.Z.J. Geol. Geophys., 7 $745-765$.

5. Eiby, G. A., 1968, "An Annotated List of New Zealand Earthquakes 1460-1965", N.Z.J. Geol. Geophys., 11 630-47.

6. Eiby, G. A., 1975, "A History of AntiSeismic Measures in New Zealand", Bull. N.Z. Nat. Soc. Earthquake Eng., 8 255-9.

7. Richter, C. F., 1958, "Elementary Seismology", W. H. Freeman \& Co., $768 \mathrm{pp}$.

8. Smith, W. D. 1976, "Statistical Estimates of the Likelihood of Earthquake Shaking Throughout New Zealand", Bull. N.Z. Nat. Soc. Earthquake Eng., 9, 213-221.

APPENDIX 3.1

Modified Mercalli Intensity Scale, 1956 Version (Richter, 1958)

Masonry A, B, C, D

To avoid ambiguity of language, the quality of masonry, brick or otherwise, is specified by the following lettering:

\section{Masonry A}

Good workmanship, mortar, and design: reinforced, especially laterally, and bound together by using steel, concrete, etc.; designed to resist lateral forces.

\section{Masonry B}

Good workmanship and mortar; reinforced, but not designed in detail to resist lateral forces.

\section{Masonry C}

Ordinary workmanship and mortar; no extreme weaknesses like failing to tie in at corners, but neither reinforced nor designed against horizontal forces.

\section{Masonry D}

Weak màterials, such as adobe; poor mortar; low standards of workmanship; weak horizontally.

\section{Intensity Scale}

I. Not felt. Marginal and long-period effects of large earthquakes.

II. Felt by persons at rest, on upper floors, or favourably placed.

III. Felt indoors. Hanging objects swing. Vibration like passing of light trucks. Duration estimated. May not be recognised as earthquake.

IV. Hanging objects swing. Vibration like passing of heavy trucks; or sensation of a jolt like a heavy ball striking the walls. Standing motor cars rock. Windows, dishes, doors rattle. Glasses clink. Crockery crashes. In the upper range of IV wooden walls and frame creak.

V. Felt outdoors; direction estimated. Sleepers awakened. Liquids disturbed, some spilled. Small unstable objects displaced or upset. Doors swing, close, open. Shutters, pictures move. Pendulum clocks stop, start, change rate. 
VI. Felt by all. Many frightened and run outdoors. Persons walk unsteadily. Windows, dishes, glassware broken. Knick-knacks, books, etc. off shelves. Pictures off walls. Furniture moved or overturned. Weak plaster and masonry D cracked. Small bells ring (church, schcol). Trees, bushes shaken.

VII. Difficult to stand. Noticed by drivers of motor cars. Hanging objects quiver. Furniture broken. Damage to masonry $D$, including cracks. Weak chimneys broken at roof line. Fall of plaster, loose bricks, stones, tiles, cornices. Some cracks in masonry C. Waves on ponds; water turbid with mud. Small slides and caving in along sand or gravel banks. Large bells ring. Concrete irrigation ditches damaged.

VIII. Steering of motor cars affected. Damage to masonry $C$; partial collapse. Some damage to masonry $B$; none to masonry $A$. Fall of stucco and some masonry walls. Twisting, fall of chimneys, factory stacks, monuments, towers, elevated tanks. Frame houses moved on foundations if not bolted down; loose panel walls thrown out. Decayed piling broken off.
Branches broken from trees. Changes in flow or temperature of springs and wells. Cracks in wet ground and on steep slopes.

IX. General panic. Masonry D destroyed; masonry $C$ heavily damaged sometimes with complete collapse; masonry $B$ seriously damaged. Frame structures, it not bolted, shifted off foundations. Frames racked. Serious damage to reservoirs. Underground pipes broken. Conspicuous cracks in ground. In alluviated areas sand and mud ejected, earthquake fountains, sand craters.

x. Most masonry and frame structures destroyed with their foundations. Some well-built wooden structures and bridges destroyed. Serious damage to dams, dikes, embankments. Large landslides. Water thrown on banks of canals, rivers, lakes, etc. Sand and mud shifted horizontally on beaches and flat lands. Rails bent slightly.

XI. Rails bent greatly. Underground pipelines completely out of service.

XII. Damage nearly total. Large rock masses displaced. Lines of sight and level distorted. Objects thrown into the air.

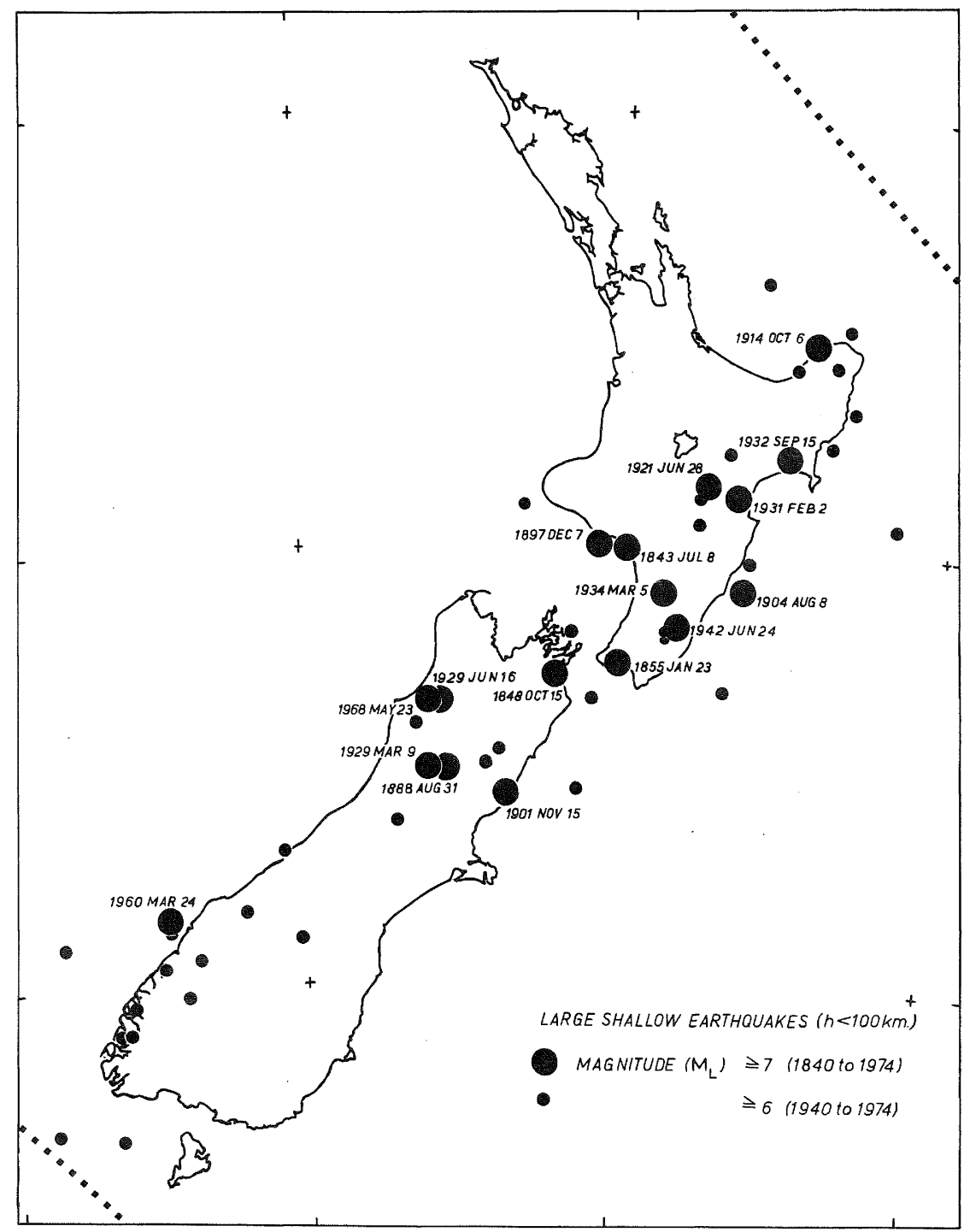

FIGURE 3.1: LARGE SHALLOW EARTHQUAKES IN NEW ZEALAND IN HISTORICALTIMES 


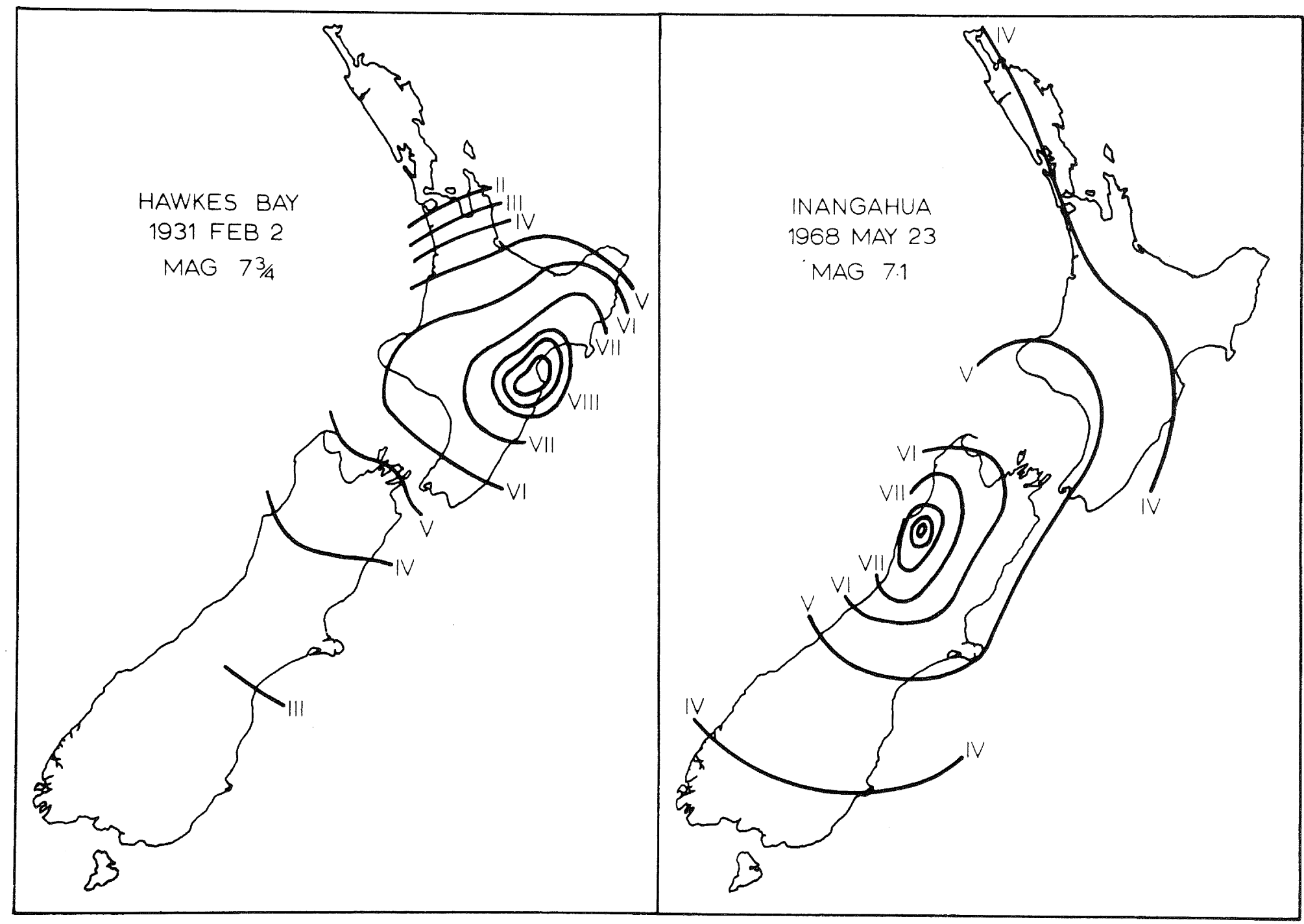

FIGURE 3.2: ISOSEISMAL MAPS (REPORTED INTENSITIES) FOR TWO LARGE SHALLOW EARTHOUAKES 


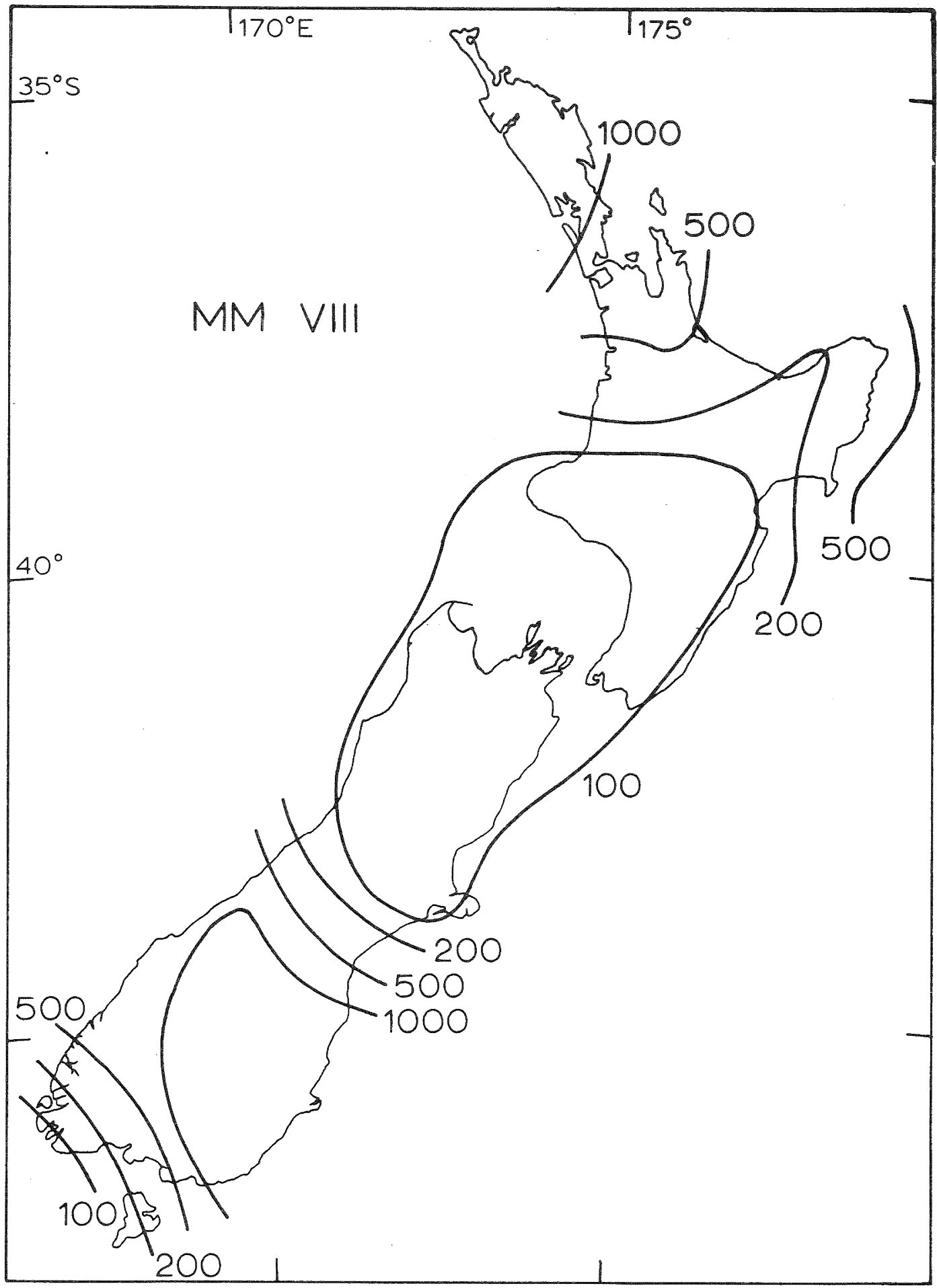

FIGURE 3.3: RETURN PERIODS (YEARS) FOR INTENSITY VIII OR GREATER THROUGHOUT NEW ZEALAND. CALCULATIONS ARE BASED ON THE OCCURRENCE OF LARGE EARTHQUAKES BETWEEN 1840 AND 1975 


\section{CRITERIA FOR DESIGN AND ASSESSMENT*}

\subsection{Criteria for Design Earthquakes}

\subsubsection{Choice of an SSE for New Zealand}

4.4.1.1 In choosing an earthquake for design purposes it is obviously desirable that its description should be consistent with that already codified by other countries where seismic design is important, particularly that of the U.S. which must be regarded as a major supplier country. It is also desirable that the trend towards rational assessment of reactor risks, which has been exemplified by the Rasmussen Study be recognised.

4.4.1.2 The Reactor Safety Study (26) has pointed the way to the assessment of the risk from a nuclear power station in a seismic region, and an application of the technique in the New Zealand context by the Ministry of Works and Development (25) has led to an assessment of the probability of core melt assuming a given level for the safe shutdown Earthquake. Consideration of this work suggests that the choice of a level of seismic design for the SSE might well be guided by the principle that the risk from an earthquake at a nuclear power plant should not add significantly to the risks arising from accidents at the reactor from other causes. It is recommended that this guideline be used.

4.4.1.3 The estimation of the earthquake risk could involve the method discussed by the M.W.D. Whatever technique is used it is apparent that the guideline will require the SSE design for a New Zealand reactor to be based on a severe earthcuake of low probability. The choice of SSE to meet the guideline will have to be justified to the Regulatory Authority by the organisation building the reactor.

4.4.1.4 The use of the U.S. definition of Safe Shutdown Earthquake is not inconsistent with the guideline and it is recommended that it be adopted for use by New Zealand. The Safe Shutdown Earthquake, as specified in the Reactor Site Criteria of the U.S. Nuclear Regulatory Commission(13) is that earthquake which is based upon an evaluation of the maximum earthguake potential considering the regional and local geology and seismology and specific characteristics of local subsurface material. It is that earthquake which produces the maximum vibratory ground motion for which certain structures,

* Chapter 4 of the 1977 Report of the New Zealand Atomic Energy Committee Working Group on Seismic Effects on Nuclear Installations. Sections 4.1 Need for Criteria, 4.2 Practice in Other countries, 4.3 The Probability Approach to Reactor Safety Analysis, 4.5 Description of Design Earthquakes and references not relevant to section 4.4 are ommitted. systems, and components are designed to remain functional. These structures, systems and components are those necessary to assure:

(I) The integrity of the reactor coolant pressure boundary

(2) The capability to shut down the reactor and maintain it in a safe shutdown condition, or

(3) The capability to prevent or mitigate the consequences of accidents which could result in potential offsite exposures comparable to the guideline exposures of this part.

4.4.1.5 The form of the specifications of the Safe Shutdown Earthquake in terms of response spectra or time histories and the detailed considerations which lead to the specifications are discussed in section 4.5 .

\subsubsection{The Need for an $\mathrm{OBE}$}

4.4.2.1 It was pointed out in section 4.2.7.2 that is is usual to consider a second design earthquake of lower intensity than the SSE. Although there is some variation in approach, this second design earthquake is typically treated in the manner of the operating Basis Earthquake $(O B E)$ of the USNRC: it defines a boundary between those earthquakes in which the plant is confidently expected to suffer no damage and those larger earthquakes following which the plant must be checked to ascertain if it has sustained any damage.

4.4.2.2 The philosophy of the OBE varies from country to country, and seems to be conditioned by the general level of seismicity in each one. In N.Z. it is likely that any nuclear installation will experience a number of earthquakes in its life. Should one of them approach or equal the SSE it is obvious (since some damage may occur in a SSE) that the plant should be shut down and not re-started until it has been inspected and found safe. But most earthquakes will be far smaller than the SSE and it is quite undesirable that they should have such consequences. Evidently the boundary between the two degrees of earthquake needs clarification by the adoption of an OBE.

4.4.2.3. In selecting an OBE many factors need to be considered. From the point of view of the owncr it is partly an economic decision, since there is a balance between the cost of designing for a large $O B E$ and the economic penalty of enforced shutdowns which will be more frequent the lower the OBE is set. But matters of public interest are involved too. It is most undesirable that any nuclear installation should acquire 
the reputation of having to be shut down after an earthquake which has caused only minor damage to conventional buildings; such a reputation must undermine public confidence. Furthermore it is not desirable that the Regulatory Authority (RA) should have to undertake a post-earthquake inspection and clearance too often. Such a task, if it has to be done at all, must be done thoroughly; at rare intervals the RA could make such special effort using additional staff seconded from other organisations; but if it were required ton often there is the danager that the execution would become perfunctory.

4.4.2.4 It follows from the above arguments that an $O B E$ should have a low probability of occurring in the life of the plant. The U.S. practice whereby the owner or operator may select the OBE provided it is not less than the minimum prescribed by the RA seems sound; it permits the owner or operator to make his own economic decisions. It remains to consider here the minimum $\mathrm{OBE}$ which the RA may require.

4.4.2.5 The U.S. regulations require an OBE not less than one half the SSE. Beyond that the literature reyeals some lack of agreement. Stevenson $(14)$ interprets it as one with a relatively high probability of occurrence in 40 years. Coulter et al (16) remark that in most cases it is the maximum historic earthquake experienced at the site and which might reasonably be expected to occur again in the life of the plant. Shukla and Kissenpfennig(15) suggest a return period of one to two times the life of the plant. The Japanese approach appears to be undergoing some changes and their OBE philosophy is not at present clear. The French, German and Italian approaches equate the OBE with the maximum historic earthquake.

4.4.2.6 In view of the short historic record of earthquakes in N.Z. there are difficulties in basing the OBE on the maximum historic earthquake at the site. An alternative approach is therefore proposed based on the following pointers.

(a) Mehta et al (17) report a survey of OBE's used for design of 67 U.S. plants and 10 in other parts of the world. Maximum horizontal ground accelerations used were:

$\begin{array}{lr}\text { less than } 0.10 \mathrm{~g} & 52 \text { plants } \\ 0.10 \mathrm{~g}-0.15 \mathrm{~g} & 23 \text { plants } \\ \text { more than } 0.15 \mathrm{~g} & 2 \text { plants }\end{array}$

(b) The range $0.10 \mathrm{~g}-0.15 \mathrm{~g}$ corresponds to the range of intensity MM VII to VIII, according to Medvedev and Spopheuer (18) and Newmark (quoted in stevenson $(14)$ ). Over most of New Zealand this covers earthquakes with return periods of around 100 years. See for example Fig. 3.3 and reference (8) of Chapter 3 .

4.4.2.7 Thus the adoption for the OBE of an earthquake with a return period of about 100 years would result in one in the range that manufacturers are accustomed to work in, and with a return period several times the life of the plant; which accords conservatively with practice in other countries.
4.4.2.8 The resulting design basis can be illustrated as follows, assuming that the OBE selected is MM VIII, with a maximum horizontal ground acceleration of $0.15 \mathrm{~g}$. If we adopt spectra from Fig. 15 of Skinner (19) and scale them to $0.15 \mathrm{~g}$ at zero period then for small damping (say $3 \%$ ) and short period (say 0.2 secs) the response factor is about $0.4 \mathrm{~g}$. This factor would be used in conjunction with stresses and deformations within the elastic range in accordance with the traditional approach of design codes. In effect the OBE design basis requires design seismic forces about 3 times as great as those applicable to conventional buildings.

4.4.2.9 It is recommended that the U.S. definition of the OBE be used, for the same reason as with the SSF, i.e. that the U.S. is a major supplier country whose standards are widely adopted. The U.S. definition is: "The earthquake which, considering the regional and local geology and seismology and specific characteristics of local subsurface material, could reasonably be expected to affect the plant site during the operating life of the plant; it is that earthquake which produces the maximum vibratory ground motion for which those features of the nuclear power plant necessary for continued operation without undue risk to the health and safety of the public are designed to remain functional."

\section{REFERENCES}

13. 10CFR 100 (1975). US Nuclear Regulatory Commission. "Reactor Site Criteria". Code of Federal Regulations Title 10. Part 100. 1975.

14. Stevenson, J. D., (1975). "Rational determination of the OBE and its impact on overall safety". Nucl. Eng. and Des. 35 (1975).

15. Shukla, D. K. and Kissenpfennig, J. F. (1976), "SSE and OBE deterministic and Probabilistic Evaluations". OECD SEN/SIN (76) 1. Paris.

16. Coulter, H. W., Waldron, H. H. and Devine, J. F. (1974), "Seismic and Geologic Siting considerations for Nuclear Facilities". Proc. 5th WCEE. Rome.

17. Mehta, D. S., Kuo, P. T. and Vizzi, A.A. (1974). "Selection of Seismic Design Parameters for a Nuclear Facility". Proc. 5th WCEE. Rome.

18. Medvedev, S. V. and Sponheuer, W., (1969). "Scale of Seismic Intensity". Proc. 4 WCEE. Santiago.

19. Skinner, R. I. (1964), "EarthquakeGenerated forces and movements in tall buildings", D.S.I.R. Bulletin 166 . Lower Hutt.

25. Ministry of Works and Development (1977). "Earthquakes and Nuclear Power Plants; an application of WASH-1400 methods in New Zealand" in second submission by Ministry of Works and Development to the Royal Commision on Nuclear Power Generation in New Zealand. April 1977.

26. United States Nuclear Regulatory Commission (1975), "Reactor Safety Study: An assessment of accident risks in U.S. Commercial Nuclear Power Plants" WASH-1400, (NUREG - 75/014). 


\section{GEOLOGICAL ASSURANCE *}

\subsection{Effects of Geological Hazards}

\subsubsection{Tectonism}

Tectonism, that branch of geology that includes the instability of the earth's crust, is demonstrated in New Zealand by small and large scale movements of the land surface which occur in time intervals ranging from fractions of a second to millions of years. The effects of recent tectonism include ground movements resulting from active faulting, warping and tilting, and ground vibrations from the earthquakes that sometimes accompany these movements. These events are almost invariably caused by natural forces in the earth's crust, but can in special cases, be produced by the activities of man.

\subsubsection{Active Faulting}

Fault movements can produce locally dramatic changes to the landscape and devastation to structures sited across or very near to them. Relative displacements of up to $12 \mathrm{~m}$ vertically, horizontally or obliquely are possible, extending with decreasing displacement over distances of $100 \mathrm{~km}$ or greater. Surface ruptures have been recorded on faults in New Zealand in at least 9 places in historic times (see Table 5.1). Many other movements have no doubt occurred also, but because they were small or in remote areas, were either not detected or not recorded.

Most known surface ruptures in New Zealand have occurred in areas remote from cities and towns. Should relative movements ranging from a few centimetres to $12 \mathrm{~m}$ occur in the future in populated areas, even modern earthquake resistant structures would be severely damaged. Overseas examples of such damage are numerous.

Ground deformation can occur also within a zone some tens of metres wide straddling a fault plane. This movement which may also be capable of seriously straining structures can take place just before or just after, as well as during, the main fault movement. The ground in this zone is permanently deformed where the non-elastic component of deformation is significantly large. Modern structural engineering technology cannot design and construct buildings that can accommodate the large relative displacements known to occur across and very close to planes of movement of active faults.

Active fault movements can cut road and

* Chapter 5 of the 1977 Report of the New Zealand Atomic Energy Committee Working Grcup on Seismic Effects on Nuclear Installations. rail transport, interrupt telephone communication, and disrupt the distribution of liquids and gas in pipe lines. The damage can be locally very severe, but is not as widespread as that caused by the accompanying earthquake engendered ground motions.

\subsubsection{Warping and Tilting}

Large areas of New Zealand have been warped, tilted and folded by tectonic movements. These processes are still active, and even in historic times have deformed large areas of our landscape. Most of the fault movements noted in Table 5.1 were accompanied by tilting, the result of either warping or near vertical displacements along the margins of fault blocks.

These movements affect large b]ocks of land and are usually barely perceptible to local residents unless there is a well defined plane of reference, such as the shoreline of the western margin of port Nicholson at the time of the 1855 west Wairarapa Fault Movement (2), or the harbour at Napier in 1931(12). Land deformation can also occur without accompanying local surface fault rupture, as a result of movements on faults at depth below the surface. Evidence for this kind of deformation is usually obtained from the attitudes of rock strata, deformation of landforms, and from resurveys of existing survey networks.

The observed effects of tilting and warping are the changed gradients of transport routes and waterways, the deepening or shallowing of bodies of water, and the migration of shorelines.

\subsubsection{Ground Motion and Ground Damage}

Ground motions (earthquakes) usually accompany fault, tilt and warp movements. The effects they have on natural landforms and man-made structures depend upon many factors including the spectral composition of the earthquake waves, the amount of energy transmitted by them, the kinds of rocks and soils through which they travel (more especially those overlying the local basement rocks), the duration of the attack, and the size, shape, and orientation of the landforms and structures(13).

Intense ground motion induced by earthquakes can cause natural ground and artificially placed fill to fail by lateral spreading, compressional buckling, landsliding and liquefaction. Weak soils, and rocks possessing many defects, are prone to failure especially where, because of geometry, water saturation or degree of weathering, they had marginal stability immediately prior to the earthquake. Steep bluffs throw off loosely jointed blocks (for example the 
limestone bluffs and steep granite slopes in the Buller Gorge during the Murchison (1929) and Inangahua (1968) earthquakes). Slopes in weak soils and soft rocks fail by rotational sliding, especially where defect attitudes are unfavourable, or where ridge or valley wall geometry favours a concentration of energy (Upper Buller Gorge and Inangahua region, 1968). Slides and falls commonly develop on slopes in hard rock.

Earthquake-induced landslides frequently cut communications and transport routes, such as telephones, railway lines, roads, bridges. They can dam rivers, or if large volumes of slide debris move rapidly into lakes and reservoirs, can displace large volumes of water at disastrously rapid rates.

Land of low or even no relief can be seriously affected by liquefaction if underlain by weak deposits such as a granular soil of low density. The passage of a seismic wave through such a deposit can cause particles to reorient towards closer packing, resulting in a volume change and an accompanying loss of bearing strength. Liquefaction raises the pore water pressure to the same values as the applied external forces and can initiate extensive sliding in both natural and man assembled soils. Earthquakes ranging in magnitude from M5.5 to M8.5 have induced liquefaction over distances of up to a few hundreds of kilometres from their epicentres (14). Sand "volcanoes" are commonly evidence in New Zealand of liquefaction and ground water pressure changes during earthquakes. Temporary and permanent changes in water levels occur frequently in both water table and artesian wells as a result of earthquakes.

\subsubsection{Tsunami}

Tsunami, sometimes referred to as seismic sea waves, are produced by ocean bottom movements, the result of either tectonism, volcanism, or submarine sliding. Those reaching New zealand originate mainly on the western coasts of North and South America, but some are generated locally.

Tsunami have sometimes caused concern in New Zealand in the past when the arrival of the peak wave coincided with high or abnormally high tides. Most vulnerable are those Pacific coastal regions exposed to wave attack from these directions.

Inundation of low-lying land has been favoured little or no dissipation of wave energy, for example in Lyttelton Harbour where the tsunami generated by the 1960 Chile earthquake produced, crest to trough oscillations of $5.5 \mathrm{~m}(15)$. Locally generated waves with amplitudes of $10 \mathrm{~m}$ have been described by observers (e.g. Gisborne 1947) but these reports are largely unsupported(16).

\section{1 .2 Volcanism}

The New Zealand volcanological record over the past few tens of thousands of years indicates that volcanic events could occur in the future that would be greater than any that has occurred in historic times. In this period apparently quiescent ground has erupted violently, and land has been covered by lava. Vegetation on vast areas of the central part of the North Island has been incinerated and buried beneath many metres of very hot pyroclastic material that has travelled at high speeds destroying all that lay in its path. Volcanic ash that has been hurled into the air many thousands of metres has fallen where the wind has blown it, to mantle the landscape and pollute waterways.

The effects of events accompanying or following volcanism are many and varied. Life is endangered by dispersed toxic gases, and structures and landforms are damaged not only by the earth deformation and earthquakes that accompany volcanic activity, but also by the effects of lahars, and obstructed and dammed water ways. Ground that was once fluid has cooled, solidified, contracted and become fissured, allowing cold meteoric water to circulate to depths where it is heated by rocks that are still hot. The rapid ascent of heated water, besides providing a notable tourist attraction and a valuable geothermal resource, has also in places created formidable engineering geological hazards.

Volcanism has cccurred in the past few thousands of years not only near the presently active volcanoes of Tongariro National Park and White Island, but also in places where volcanic activity is sometimes regarded as extinct. Eruptive activity in the Kaikohe, Auckland City, Rotorua-Taupo, and Taranki regions extended over tens of thousands of years with periods of quiescence alternating with periods of renewed activity. In most of these volcanic fields the period since the latest activity is less than the probable average period between eruptions. In Northland the latest activity was $1300-1800$ years ago and the interval between eruptions possibly $1,000-2,000$ years (17); in Auckland the latest eruption was less than 800 years ago, the intervening interval of quiescence possibly 1,000 years (18). The Rotorua-Taupo region, excluding Mts. Ruapehu, Tongariro and Ngauruhoe, experienced 27 major eruptions in the past 20,000 years with periods of quiescence ranging from 50 to 5,000 years; a violent eruption occurred in this region ca 1850 years ago the latest eruption was only 90 years ago(19). The most recent activity on Mount Egmont occurred about 300 years ago $(20)$. Volcanism cannot therefore be regarded as extinct in any of these regions.

\subsubsection{Subsidence and Collapse}

The ground surface in a number of small areas in New Zealand is known to have subsided after coal or hot water and steam have been extracted. Areas greater than a few tens of square kilometres have been affected, with settlement rates exceeding $0.5 \mathrm{~m} / \mathrm{yr}$. Craters have been formed as a result of near-surface mining. Subsidence has also followed surface collapse into solution channels in limestone. Sinkholes tens of metres across, extending to a similar depth, are typical landscape features in limestone terrain.

\subsection{Geological Investigations}

Any site selected for a nuclear power station will need to meet stringent siting 
criteria. The application of such criteria should ensure that there will be an acceptably low risk of the ground beneath structures being displaced by fault movements or deformed by major tilting, of the effects of volcanism, and of subsidence or of other kinds of ground damage. It should ensure also that sufficient data have been obtained to assess the response and behaviour of the rock at and near the site to earthquakes. These criteria each site must be fully investigated using appropriate field and laboratory methods.

\section{2 .1 Objectives of Geological Investigations}

Investigations must aim at the recognition, classification, and evaluation of relevant geological hazards. They will need to encompass both the past and recent geological history of the region, and in particular the past and present day tectonism and volcanism. Essential to this is a chorough understanding and knowledge of regional and lccal yeology, and the behaviour under seismic, and other kinds of loading, of those features of the landscape and the rocks and soils comprising them that are of significance to the siting of nuclear power stations.

Investigations should include, besides the assessment of previous investigations, detailed surface and subsurface engineering geological mapping using conventional geological, geophysical, geomechenical, seismological and geodetic practices, and where appropriate, continual monitoring in these fields $(21)$.

\subsubsection{Remote Sensing Techniques}

Imagery of various kinds (Landsat, Side Looking Airborne Radar (SLAR), and high level aerial phctography and aeromagnetics) provides a broad overview that indicates structural trends, for example long fault traces, lineaments, and alignments of volcanic vents. These techniques do not precisely define the nature of each geological structure, but they may indicate features that need closer aerial, and possibly detailed surface and subsurface examination. Low level vertical and oblique aerial photographs and aerial reconnaissance further refine the regional approach, and are valuable in precisely locating and mapping fault traces and other geomorphic features.

\subsubsection{Surface Geological Methods}

Surface geological mapping is essential to the study of stratigraphic sequence, structure, and geomorphic features, and forms the basis of all investigations. Conventional geological techniques can be effectively employed in both reconnaissance and detailed site investigations.

\subsubsection{Subsurface Geological Methods}

Detailed investigations are aimed at demonstrating that selected candidate sites meet regulatory authority criteria.

Subsurface investigatjons use soil and rock stratigraphic sequences and various dating techniques to date past events, and to demonstrate that active faulting, earthquakes, and volcanism are not likely to adversely affect any nuclear power station site.
Conventional site investigation methods can be used, including drilling, trenching, and the excavation of adits, shafts and bulldozer cuts. The standard of drilling, documentation, and interpretation must be very high to ensure that the significance of small scale geological features is not lost. Sophisticated dating methods (including $\mathrm{Cl} 4, \mathrm{~K} / \mathrm{Ar}$, paleomagnetic and fission track) must be used where appropriate to determine the age of past events. It is largely upon dating that the classjfication of these events rely.

\subsubsection{Geophysical Methods}

Surface and subsurface geological data are commonly inadequate for precise interpretation, and often need to be enhanced by those geophysical techniques that are appropriate to a specific geological environment. Seismic refraction and reflection, magnetic, gravity, and resistivity traverses on land and offshore enhance interpretation of local geology, and enable the direct methods to be used more effectively in subsequent site investigations. Downhole techniques, electrical logging, (including resistivity, self potential and gamma), seismic and acoustic, can facilitate a more accurate determination of stratigraphic sequence in drill holes. Downhole methods using shear and compressional wave velocities are useful also in assessing ground response and shear and dynamic elastic moduli.

Macro and micro seismic activity can sometimes be used to indicate zones of activity on faults with or without surface expression. The reverse, that lack of seismic activity on geologically determined active faults indicates inactivity, does not hold; this is in part because the period of seismological observation is short when compared with that of the geological record.

\subsubsection{Ground Water}

The distribution of groundwater and its rate and direction of movement can be determined using conventional methods. This information is of value in construction where large excavations need dewatering, and in the prior assessment of pollution control measures that might be needed during operation.

\subsubsection{Geomechanical Methods}

Geomechanical field and laboratory methods are used to evaluate the physical properties of the soil and rock masses on which a nuclear power plant is to be sited, and in which natural and man-made slopes may be cut. The values obtained, when interpreted with detailed local geology, provide basic design data for the assessment and construction of foundations and slopes in the environs of the site.

of special significance in nuclear power plant design is the response of the ground to earthcuake excitation from underlying base rock. The dynamic and static 
properties of rock and soil can be tested in the laboratory using modern techniques, but these do not necessarily accurately represent the properties of large masses of rock and soil in situ. Similar, but larger scale tests can be performed more effectively in situ. In situ testing should be undertaken where the accurate quantification of design parameters is critical.

\subsection{Assessment of Engineering Geological Hazards}

The most effective assurance against geological hazards is prudent site selection. Geological assessment is aimed at defining the limits of attack as closely as possible so that these can be allowed for in design. Sites which cannot meet safety, engineering design, or economic criteria must be avoided. The effects of geological hazards can be significantly reduced by setting sites back from the most hazardous areas by distances appropriate to each hazard and region.

\subsubsection{Active Faulting}

Earthquake-producing fault movements in the earth's crust cause surface rupture where the earthquake magnitudes are large and the depths of foci are shallow.

Geological structures capable of producing surface rupture can be identified by the evidence of past tectonism (commonly fault, tilt and warp movernents in the past 500,000 years), and by evidence of present day macro or micro seismicity.

Fault displacements of up to $12 \mathrm{~m}$ are possible on most active faults in New Zealand, and as it is not yet possible to predict when or where future movements will occur, the assumption must be made that movements on all sections of all active faults are equally probable.

Damaging movements can result from direct rupture along the fault plane of a principal fault, or along one of its branch or secondary faults. They could also result from movements on a new fault, but the chances of new primary faulting occurring in a place where there was no evidence of previous faulting are very low indeed. It is possible, however, that secondary faulting, perhaps as bedding plane faults and ground damage, could be induced by faulting nearby, or by earthquake-induced ground motions. The probability of these occurring diminish with increasing distance from known active faults. Shear, compressional buckling, and tensional movements in zones adjacent to active fault planes can also cause damage. The shape and size of these zones differ with different kinds of fault movements. Transcurrent faulting produces damage that is largely localised along relatively narrow zones. Normal faulting produces a wider zone of damage, most of which is on the downthrown side. Reverse faulting can produce extensive damage on the upthrown side but much less on the downthrown side (22) The zoning of hazard for nuclear power station siting must reflect the kind of fault movements expected.

\subsubsection{Classification}

An active fault can be defined loosely as a fault that has moved in the recent past and is thought likely to move in the near future. Classifications of active faults (see Appendix 5.1) become important only in the way that they relate to hazard assessment and design.

There are two main difficulties in classifying the "activity" cf faults. One arises from the difficulties of determining the age of past movements, the other from the uncertainty of the maximum interval without activity after which movement on a fault is still possible. The White Creek Fault which moved during the 1929 Murchison earthquake, for example, had not previously moved at the site of the 1929 displacement, judged on detailed investigations, for more than 18,000 years (pers. comm. R. P. Suggate).

Though it is not possible to positively identify faults that will or will not move in the lifetime of civil engineering structures, it is possible to identify the faults that, because of their history of past movements are considered likely to move in the future.

The most significant criteria used to determine the "activity" of a fault are the age of the latest movement, and the frequency of movement. The dating of past movements is a single most important criterion. This can be achieved in a number of ways, but the evidence necessary is not everywhere available. Fault movements can be dated by physiographic, stratigraphic, radiometric or paleomagnetic methods. Stratigraphic methods depend on a knowledge of the age of geological formations. The age of a fault lies between the age of the youngest deposit that has been displaced by fault movements, and the age of the oldest deposit (if any) that has not been displaced. Methods commonly used to date constituents of the various formations, include Cl4 dating of carbon from organic material, and paleomagnetic, potassium-argon and fission-track methods to date various minerals. Morphological methods can also be used.

Dating becomes very imprecise where datable material cannot be found, or where the youngest formation displaced is more than 500,000 years old, or where this is overlain by a very young deposit. The age of movements at such faults cannot be demonstrated unless acceptable evidence can be found elsewhere along its length.

An attempt at assessing a minimum frequency of movement in a tectonically active area might be made from the amount of displacement, the age of the displaced rocks, and the probable maximum displacement during one event.

Field evidence is sometimes inadequate to unequivocally classify a fault or a fold as active, as datable material is sparse, and the processes of erosion, deposition, and human occupation in time obliterate diagnostic small-scale land surface features. There is a need in nuclear siting to include in the active category those faults and folds which probably would have been classified as active, had these features been preserved. The criteria that can be used to assign structures to potentially active classes (see Appendix 5.1) include 
the similarity of their structural trends and size, attitudes of rocks, and physiography, to known active faults and folds in the same tectonic regime. For nuclear siting potentially active features must be assessed as if they were active.

\subsubsection{Ground Vibrations near Active Faults}

Active fault movements can be accompanied by locally strong ground motions. The distance that a station should be set back from a tault should include not only the zone in which secondary faulting is possible. but also the zone in which the earthquake engendered ground motions have the potential to cause damage.

At present much reliance is placed overseas on compilations and assessments of world-wide data relating earthquake magnitude, fault length, amount of displacement, ground acceleration, and attenuation $(13,23)$. This kind of approach could be followed in New Zealand, but only after critical evaluation and modification where necessary.

\subsubsection{Tilting and Warping, Folding and Associated Faulting}

\subsubsection{Tilting and Warping}

Large blocks of land in New Zealand have been tilted and warped by tectonic movements in historic and geologic times. Some of these have been bounded on one side by major faults with surface expression (for example West Wairarapa, 1955), others have been underlain by faults that have moved at depth but have had insufficient displacement or too great a depth of burial beneath deformable deposits to produce surface fault displacement. Individual surface movements of this kind are mostly small in engineering terms but should be considered in siting.

The relevant parameters (amounts and frequency of movement) can often be inferred in regional terms of geological evidence. It is reasonabie to assume that the degree of tilting and significance to engineering will be smaller a few tens of kilometres distant from fault planes or axes of warping than they will be closer to these; such tilts from a single movement could possibly be of the order of 1 in 10,000 to 1 in 5,000. closer to a fault or axis of warping, greater tilting can be expected, possibly in the order of 1 in 1,000; it could be considerably greater within a few metres of the fault plane.

The hazard of tilting and warping can be assessed in siting studies by recognizing and identifying causative structures, and assessing rates and amounts of past deformation. Zones can be set around these structures with set-back distances sufficiently large to ensure that sites will not be selected in which tilts will be likely to exceed design criteria. Where absolute altitudes, as distinct from relative displacements are significant, for example for cooling water supplies, the effects of uplifts of up to $12 \mathrm{~m}$ must be evaluated.

\subsubsection{Folding and Associated Faulting}

Primary faulting in basement rocks can be reflected as folding in the less brittle covering strata, for example in the siltstones and mudstones of mainly Tertiary age in New Zealand. The thickness and stiffness of these younger beds, and the magnitudes of the displacement in the basement, control whether the deformation at the surface will be faulting or folding, and the nature of folding and any associated secondary faulting.

Fault-induced folding can usually be expected to produce surface deformation as a result of any one event that is similar in magnitude to that of tilting; transcurrent buckling may be larger and extend over smaller distances. Secondary faulting in the limbs of the folds can result from the continued development of folding. The attitude (strike and dip) of these folds, and the risk from future movement will depend on the tectonic regime and the proximity and kind of dominant basement faulting. The tectonic environments of each candidate area or tentatively selected site must be carefully studied, and an assessment made of the likelihood of future folding and secondary faulting that could accompany basement faulting and folding in regions of thick covering strata.

\subsubsection{Seismotectonic Analysis}

A rational approach to the recognition and identification of active geological structures capable of producing earthquakes and earth deformation uses existing knowledge of geological structure and seismicity $(13,21,23)$. In this a seismicity map and a structural geology map are combined to show areas possessing sets of similar hazards, these being assigned hazard values. In many areas of New Zealand no readily discernible pattern may emerge from the distribution of epicentres and geological structures, possibly in part because of the short seismic record, but the approach is worthy of further study.

\subsubsection{Ground Motion and Ground Damage}

Large areas of New Zealand are periodically shaken by seismically induced ground motions. Many of the earthquakes that cause damage originate from foci that cannot be identified with any known geological fault on land or beneath the sea. Less commonly, but with disastrous local effects, ground motions accompany surface fault displacement; these occur only with large earthquakes.

All major earthquakes produce some ground damage, the extent depending upon the earthquake parameters (magnitude, spectral composition, duration, acceleration), topography, and the physical properties of rock mass and soil overlying the local basement rocks.

The principal defence against ground damage and other effects of ground motions is effective hazard assessment, followed by either appropriate engineering design or the selection of other sites where the risks from these hazards are acceptably low.

The consequences of failure of natural and man-made slopes in the vicinity of the site, whether seismically induced or not, need to be assessed. Where the failure is likely to affect the safety of the station 
itself or of water retention or transportation structures, sophisticated methods of slope stability analysis and engineering design are essential.

Where the detailed soil mechanics investigations indicate a potential for liquefaction, this must be evaluated using appropriate dynamic, or other equally effective methods. The effects and consequences of liquefaction induced by the Safe Shutdown Earthquake (SSE) must be assessed.

\section{3 .5 Tsunami}

The coastal regions of New Zealand most vulnerable to tsunami attacks are those exposed to waves advancing from the Pacific region, notably from the western coasts of North and South America, and those close to regions of potential ocean bottom disturbances.

Assessment of the hazard is based on past tsunami attack from distant and local sources, and on studies designed to predict the effects of coastal, harbour and embayment geometry on tsunami wave run up and draw down $\{21\}$.

Site selection should assess the vulnerability of a site to attack, estimate the size of the largest wave expected, and discuss the frequency of attack. A zoning of tsunami hazard would be possible for regional siting studies. Where the attack is expected to be too severe to be accommodated in engineering design, other sites should be sought.

\subsubsection{Volcanism}

Active volcanism can be defined for the purpose of nuclear siting in a way analogous to active faulting.

The most effective defence against volcanic hazards is either to site plants only in those areas where this risk is acceptable low, or to avoid all areas where there is likely to be even a small risk. These both presuppose a competent prior assessment of the hazards.

Geological investigations provide evidence of the time and nature of past events; forward extrapolation from these gives a largely intuitively based quasistatistical assessment of future events. The confidence limits that can be assigned to these must necessarily be wide where they are based on few data which represent events occurring infrequently over long periods.

Volcanic hazards can be assessed by either deterministic or probabilistic methods. A deterministic approach could be especially appropriate in regions where volcanism follows well understood patterns and has clearly discernible geographic and chronological trends. The width and shape of hazard zones would reflect the kinds of past and expected future volcanism, the explosive potential of the event, and the areas or channels on to which or down which eruptive materials could be distributed; they would also reflect the degree of conservatism adopted. The probabilistic approach could be used wherever there are adequate basic data, but it lends itself especially to the study of large active volcanic fields in which there have been numerous volcanic events from widely separated vents, which do not exhibit discernible geographic or chronological trends. The probabilistic approach would aim to quantify the risk in terms that would facilitate comparison with other natural and man-induced risks. It would have merit in regions where the exclusion of large areas is justified by the density of eruptive centres and distribution of eruptive material, and where some slight volcanic risk can be tolerated.

Site acceptability must be dependent not only upon the proven low risk of exposure to direct volcanic attack, but also on low risks from indirect attack. Assurance must be demonstrated that volcanic activity and its ejecta and induced effects, including lahars, are unlikely to disastrously change natural or manmade waterways and transport routes, or adversely affect plant installations or operation, and that volcanic-induced air and water pollution can be accommodated in station design and operation.

\subsubsection{Subsidence and Collapse}

The areas in New Zealand most vulnerable to subsidence are those in which there is or has been underground mining or the extraction of hot water and steam. Subsidence is possible in the lifetime of a nuclear plant in areas underlain by exploitable deposits of coal and other hydrocarbons, and hot and cold water and steam. The potential for subsidence must be evaluated and its consequences assessed. This will require some knowledge of the resources and their confining beds, and the effects of extraction on these.

\section{REFERENCES}

1. McKay, A., 1886, "On the Geology of the Eastern Part of Marlborough Provincial District". N.Z. Geol. Surv. Rep. Geol. Explor. 1885, 27-136.

2. Ongley, M., 1943a, "Surface Trace of the 1855 Earthquake". Trans. Roy. Soc. N.Z. $73,84-80$.

3. MCKay, A., 1890, "On the Earthquakes of September 1888 in the Amuri and Marlborough Districts of the South Island". N.Z. Geol. Surv. Rep. Geol. Explor. 1888-1889, 1-16.

4. Grange, I. I., 1932, "Taupo Earthquakes 1922". N.Z. Jl. Sci. Tech. 14, 139-141.

5. Fyfe, H. E.. 1929, "Movements on the White Creek Fault, N.Z.". N.Z. J1. Sci. Tech. 11, 192-197.

6. Henderson, J., 1937, "The West Nelson Earthquakes of 1929". Bull. Dep. Sci. Ind. Res. 55.

7. Henderson, J., 1933, "The Geological Aspects of the Hawkes Bay Earthquakes". Bull. N.Z. Dept. Sci. Ind. Res. 43.

8. Walshe, H. E., 1937, "Earth Movements in Hawkes Bay District Disclosed by Triangulation", N.Z. Jl. Sci. Tech. 18, $852-4$.

9. Ongley, M. 1943B, "Wairarapa Earthquake of 24 June, 1942 together with map Showing Surface Traces of Faults Recently Active". N.Z. J1. Sci. Tech. 25, 67-78.

10. Lensen, G. J., 1970, "Elastic and 
Non-Elastic Surface Deformation in N.Z.". Bull. N.Z. Soc. Earthquake Eng. 3(4), $131-147$.

11. Lensen, G. J. and Otway, P. M., 1971, "Earthshift and Post Earthquake Deformation Associated with the May 1968 Inangahua Earthquake, New Zealand, R. Soc. N.Z. Bull. 9, 107-116.

12. Marshail, P., 1933," "Effects of Earthquake on Coast-Line near Napier", N.Z. Jl. Sci. Tech. 15(1), 79-92.

13. Oborn, L. E., 1974, "Seismic Phenomena and Engineering Geology". Proc. 2nd Int. Congr. Int. Assoc. of Eng. Geology, Sao Paulo, Brazil, l, Th II, GR-1-4l.

14. Seed, H. Bolton, 1968, "Landslides During Earthquakes Due to Soil Liquefaction". Journal of the Soil Mechanics and Foundations Division, Proceedings of A.S.C.E. Vol. 91, No. SM5, September 1968 .

15. Heath, R. A., 1976, "The Response of Several New Zealand Harbours to the 1960 Chilean Tsunami". Roy. Soc. N.Z. Tsunami Research Symp. 1974. Bull. 15.

16. Laing, A.C.M., 1954," Note on Tsunamis Reaching New Zealand". N.Z. Jl. Sci. Tech. Section. B 35(6), 470-2.

17. Kear, D. and Thompson, B. N., 1964, "Volcanic Risk in Northland", N.Z. Jl. Geol. Geophys. 7, 87-93.

18. Searle, E. J., 1964, "City of Volcanoes. A Geology of Auckland." Paul's Book Arcade Auckland and Hamilton.

19. Nathan, S., 1976, "Taupo Volcanic Zone outline of Geology", 25th Int. Geol. Congr. Excursion Guide No. 55A and 56A. Volcanic and Geothermal Geology of the Central North Island, New Zealand. Table 2, p. 12 .

20. Grant-Taylor, T. L., 1964, "Volcanic History of Western Taranaki". N.Z. Jl. Geol. Geophys. 7, 78-86.

21. International Atomic Energy Agency. Division of Nuclear Safety and Environmental protection. 1975. Safety Guide on Earthquakes and Associated Topics for Nuclear Power station Siting. International Atomic Energy Agency unpublished pp. $34+$ append.

22. Cluff, L. S., Slemmons, D. B. and Waggoner, E. B., 1970, "Active Fault Zone Hazards and Related Problems of Siting Works of Man". Proc. 4th Int. Symp. on Earthquake Engineering Technology. Nov. 1970. Roorkee, V.P. India, p. 401-410.

23. U.S. Nuclear Regulatory Commission 1975, "Seismic and Geologic Siting Criteria for Nuclear Power Plants". U.S. Nuclear Regulatory Commission. Rules and Regulations. Title 10, Chapter 1 CFR Part 100. Appendix A.

\section{APPENDIX 5.1}

\section{Definitions of Active and Potentially Active Geological Structures*}

The definitions used are based on the assessment of field evidence that is commonly available. It is implicit in these that additional data may demand that the activity of a structure be re-defined. The use of the concepts of potentially active faults and folds significantly reduces the likelihood of geologically active structures escaping

* These definitions have been adopted by the N.z. Geological Survey. detection in nuclear power siting.

\section{ACTIVE FAULT}

A fault along whose trace there is either evidence of movement in the past 50,000 years, or evidence of repeated movement in the past 500,000 years.

\section{POTENTIALLY ACTIVE FAULT}

A geologically identified fault along which no evidence of movement in the past 50,000 years, or of repeated movement in the past 500,000 years, has been preserved, but which has a trend, length and physiographic expression simiiar to those of the principal active faults in the same tectonic regime.

\section{ACTIVE FOLD}

A fold along whose length there is either evidence of movement in the past 50,000 years or evidence of repeated movement in the past 500,000 years.

\section{POTENTIALLY ACTIVE FOLD}

A geologically identified fold along which no evidence of movement in the past 50,000 years, or of repeated movement in the past 500,000 years, has been preserved, but which has a trend and magnitude, judged by deformed or displaced surfaces or sediments, similar to those of the principal active folds in the same tectonic regime.

NOTE

Active and potentially active faults and folds can be subdivided into classes which reflect degrees of past activity, but in nuclear power plant siting all active and potentially active geological structures must be assessed as if they had the highest degree of activity. 
TABLE 5,1

HISTORIC FAULT AND TILT MOVEMENTS IN NEW ZEALAND

See References

dat from C. J. Lensen (pers. comm.)

MM - Modified Mercalli Scale

M - Richter Scale

* - Approximate or deduced value

\begin{tabular}{|c|c|c|c|c|c|c|c|c|c|c|c|c|c|}
\hline \multirow{2}{*}{ DATE } & \multirow{2}{*}{ LOCATION } & \multirow{2}{*}{ NAME OF FAULT } & \multicolumn{3}{|c|}{ ASSOCIATED EARTHQUAKE: } & \multicolumn{2}{|c|}{$\begin{array}{l}\text { MAXIMUM } \\
\text { DISPLACEMENT } \\
\text { OBSERVED OR } \\
\text { DEDUCED }\end{array}$} & \multirow{2}{*}{$\begin{array}{c}\text { OBSERVED } \\
\text { LENGTH } \\
\text { OF TRACE } \\
(\mathrm{km})\end{array}$} & \multicolumn{3}{|c|}{$\begin{array}{l}\text { ESTIMATED DIMENSIONS } \\
\text { OF DEFORMED BLOCK }\end{array}$} & \multirow{2}{*}{$\begin{array}{l}\text { MAX. ANGLE } \\
\text { OF TILT } \\
\text { SECS OF } \\
\text { ARC (") }\end{array}$} & \multirow{2}{*}{ COMMENTS } \\
\hline & & & Name & $\begin{array}{l}\text { Inten- } \\
\text { sity } \\
\text { (MM) }\end{array}$ & $\begin{array}{c}\text { Mag- } \\
\text { nitude } \\
\text { (M) }\end{array}$ & $\begin{array}{l}\text { Hori. } \\
(\mathrm{m})\end{array}$ & $\begin{array}{l}\text { Vert. } \\
\text { (m) }\end{array}$ & & $\begin{array}{l}\text { Length } \\
(\mathrm{km})\end{array}$ & $\begin{array}{r}\text { Width } \\
(\mathrm{km})\end{array}$ & $\begin{array}{l}\text { Area } \\
\left(\mathrm{km}^{2}\right)\end{array}$ & & \\
\hline $\begin{array}{l}1 / 3848 \\
(10 \text { Oct })\end{array}$ & $\begin{array}{l}\text { Awatere } \\
\text { Valley }\end{array}$ & Awatere & $\begin{array}{c}\text { NE } \\
\text { Marlborough }\end{array}$ & 10 & $7-7.5^{*}$ & 6.5 & 0.3 & 96 & & & & & \\
\hline $\begin{array}{l}2 / 1855 \\
(23 \text { Jan })\end{array}$ & Wairarapa & West Wairarapa & $\begin{array}{c}\mathrm{J} 855 \\
\text { Wairarapa }\end{array}$ & ] ]* & $8^{*}$ & ca. 12 & 2.7 & $\mathrm{~J} 60$ & 360 & 32 & 5] 00 & ]" & $\begin{array}{l}\text { Based on } 3 \mathrm{~m} \\
\text { uplift at } \\
\text { Mukamuka, and zero } \\
\text { at Plimmerton }\end{array}$ \\
\hline $3 / 1888$ & Glynwye & Hope & & 9 & 7* & 3 & & & & & & & \\
\hline $4 / 1922$ & Near Taupo & $\begin{array}{l}\text { Whakaipo } \\
\text { Kaipo } \\
\text { Whangamate }\end{array}$ & & & & & 3.6 & ca. 35 & ]0 & $\begin{array}{l}20 \\
35\end{array}$ & 350 & $\begin{array}{c}\text { (Whakaipo) } \\
80^{\prime \prime}\end{array}$ & $\begin{array}{l}\text { Kaipo Graben } \\
\text { tilted to east }\end{array}$ \\
\hline $\begin{array}{l}5,6 / 929 \\
\text { (1) June) }\end{array}$ & $\begin{array}{l}\text { Buller River } \\
\text { (Upper Gorge) }\end{array}$ & White Creek & Murchison & ]1] & $7.75 *$ & 2.] & 4.6 & ca. 8 & 10 & 15 & 350 & $60 "$ & \\
\hline $7 / 3$ (3 Feb) & Napier & $\begin{array}{l}\text { Several traces at } \\
\text { Paki Paki }\end{array}$ & Napier & ] ] & 7.75 & 2 & 3.8 & & 96 & 16 & 1500 & $60 "$ & $\begin{array}{l}\text { Regional uplift } \\
\text { and traces near } \\
\text { Paki Paki }\end{array}$ \\
\hline $8 / 1932$ & Wairoa & & Wairoa & 8 & 7.25 & 0.6 & $\begin{array}{l}\text { Surface } \\
\text { slumping } \\
\text { only }\end{array}$ & & & & & & $\begin{array}{l}\text { Deformation of } \\
\text { triangulation } \\
\text { network }\end{array}$ \\
\hline $9 / 1942$ & $\begin{array}{l}\text { E. of } \\
\text { Masterton }\end{array}$ & $\begin{array}{l}\text { Un-named fault } \\
N \text { of Tauwera }\end{array}$ & Masterton & 8 & 7 & & & 3.6 & & & & & $\begin{array}{l}\text { Small trace of } \\
\text { fissures only }\end{array}$ \\
\hline $10 / 3966$ & $\begin{array}{l}\text { South of } \\
\text { Seddon }\end{array}$ & Hog swamp & Seddon & 8 & 6.1 & 0.3 & & & & & & & $\begin{array}{l}\text { No surface fault- } \\
\text { ing, crustal } \\
\text { shortening } \\
\text { ca. } 0.3 \mathrm{~m}\end{array}$ \\
\hline $11 / 1968$ & Inangahua & $\begin{array}{l}\text { Glasgow (and new } \\
\text { bedding faults at } \\
\text { Rotokohu and Rough } \\
\text { Creek) }\end{array}$ & Inangahua & $10-1]$ & 7 & 1.8 & $\begin{array}{l}\text { Regional } \\
\text { uplift } \\
2.7\end{array}$ & $\begin{array}{c}\text { Glasgow } \\
1, \\
\text { Rotokohu } \\
1.3\end{array}$ & 45 & 3] & 3400 & $35^{\prime \prime}$ & \\
\hline
\end{tabular}

